\title{
1トム力鉱山
}

\section{Itomuka Mine}

\author{
正会員 安 達 和 夫* 正会員 北 村 元 伸 ${ }^{* *}$ \\ Kazuo ADACHI Motonobu KITAMURA
}

\section{1. 緒言}

当山は北海道常呂郡留辺嶨町にあり, 通洞坑, 採鉱事 務所は標高 $1,000 \mathrm{~m}$ 泣置している。

昭和12年に発見され，同14年よりレトルト炉による操 業が開始された。その後逐次設備の拡張, 改善がなされ， 本邦水銀生産の大部分を占めるにいたり，最盛期には年 間生産量 $130 \mathrm{t}$ 亿達した。その間露頭部より垂直 $15 \mathrm{~m}$ 間 隔で12番坑まで開発された。現在の主要採掘区域は露天 採掘場から10番坑までで，年間採掘粗鉱量約 $45,000 \mathrm{t}$, 生産水銀量約 $90 \mathrm{t}$ となっている。（第 1 表，第 2 表）

\begin{tabular}{|c|c|}
\hline 第 1 表 & $\begin{array}{l}\text { 鉱量 } \\
\text { 鉱品位 } \\
3 \text { 月実績 }\end{array}$ \\
\hline \multirow{2}{*}{$\begin{array}{c}\text { 粗. 鉱 量 } \\
(\mathrm{t})\end{array}$} & 品 位 \\
\hline & $\mathrm{Hg}(\%)$ \\
\hline 4,330 & 0.15 \\
\hline
\end{tabular}

第 2 表 従業員 (42年 3 月実續)

\begin{tabular}{l|r|r|r}
\hline & 坑内 & 坑 外 & 計 \\
\hline 職 & 11 & 30 & 41 \\
賞 & 148 & 70 & 218 \\
臨 & 5 & 53 & 58 \\
計 & 164 & 153 & 317 \\
\hline
\end{tabular}

\section{2. 地 質・鉱 床}

付近の地質は日高系の粘板岩, 新第三系の変朽安山岩, 緑色凝灰岩およびこれら岩層を被覆する石英粗面岩質, 熔結凝灰岩，武華岳熔岩類に区分される。

鉣床は変朽安山岩中に発達する断層性裂力および破砕 帯に胚胎する浅熱水性裂力充填鉱床で，7 本の東西采， 南傾斜の鉣脈と北傾斜破砵帯中に点在する塊状鈗体から なる。鉱脈法概して両端が北代彎曲尖滅する三日月形を なし，その代表的な 5 号銿は走向延長 $120 \mathrm{~m}$ ，傾斜延長 $240 \mathrm{~m}$ 余, 脈幅は平均 $3 \mathrm{~m}$ 幅で最大幅 $15 \mathrm{~m}$ に達するもの もある。塊状釷体として賦存する 7 号銿群は不規則扁平 塊状をなし，各単位鉱体の規模は $5,000 \sim 15,000 \mathrm{t}$ の鉱 量となつている。鈗石は自然水銀，辰砂からなり，その 比7：3と自然水銀を多量に産する特質を有する。随伴鉱 物として白鉄鉱，黄鉄鉱，石英，方解石などを伴う。

\section{3. 採掘法}

\section{$3 \cdot 1$ 採掘法概要}

* 野村鈗業株式会社本社技術部

** 野村鉱業株式会社イトムカ釷業所
鉱床の特質として，鉱脈の膨縮が激しいこと，自然水 銀を多量に産すること，上下盤とも軟弱で剥離性に富む ことなどがあるため，支柱施工および完全充填を行なわ ねばならない。したがつて低能率ではあるが，上向水平 段欠充填法 (いわ昍る水平スライス法) および露天掘下 浅所でサブレベルケービング法を適宜採用している。両 法の採用により次のような効果をあげている。

a) 鉣脈の膨縮 $(0.5 \sim 15 \mathrm{~m})$ が激しく，中石があつて も採掘実收率が高くなつた。

b ） 2 段払抢よび下向き（サブレベルケービング法） のため，自然水銀の回収率が向上された。

c）切羽選鈗ができ，品位の維持が容易となつた。

d）小規模切羽の数を増して早く終掘させ，運搬坑道 の維持費が割安となつた。

e ）作業切羽の空間縮少により，落石落盤などの災害 が減少した。(第 $3 ， 4 ， 5$ 表)

第 3 表 出鉱量および切羽数 （42年 3 月実績）

\begin{tabular}{|c|c|c|c|c|c|}
\hline & 出捈量 & 出釷比率 & 切羽数 & 備 & 考 \\
\hline & $3,951 \mathrm{t}$ & $91.2 \%$ & 28 & $\begin{array}{l}\text { 步 } 2 \text { 段払水平段 } \\
\text { 変形トップスラ }\end{array}$ & $\begin{array}{l}\text { 欠充填洼 } \\
\text { シン法 }\end{array}$ \\
\hline $\begin{array}{l}\text { 開さ } \\
\text { 堡の地上鉱 } \\
\text { 穵 }\end{array}$ & $\begin{array}{r}140 \\
228 \\
11\end{array}$ & $\begin{array}{l}3.2 \\
5.3 \\
0.3\end{array}$ & $\begin{array}{l}1.5 \\
4.5 \\
-\end{array}$ & 坑道延長 $35.80 \mathrm{~m}$ & \\
\hline 合計 & 4,330 & 100.0 & 34 & & \\
\hline
\end{tabular}

第 4 表 開探出鉱量および試錐延長 （42年3月実績）

\begin{tabular}{|c|c|c|c|c|c|}
\hline 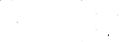 & \multirow{2}{*}{$\begin{array}{c}\text { 試錐延長 } \\
\text { (m) }\end{array}$} & \multirow{2}{*}{ 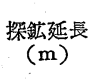 } & 出 & \multicolumn{2}{|c|}{ 量 (t) } \\
\hline & & & 開探釷 & 鉣 & 計 \\
\hline 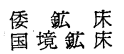 & $\begin{array}{l}252 \\
284\end{array}$ & $\begin{array}{l}34.30 \\
71.60\end{array}$ & $\begin{array}{l}0 \\
0\end{array}$ & $\begin{array}{r}4,330 \\
0\end{array}$ & $\begin{array}{r}4,330 \\
0\end{array}$ \\
\hline
\end{tabular}

\section{2 採掘準備および採掘}

上下間隔 $15 \sim 30 \mathrm{~m}$ の銿押坑道を開さくし，水平間隔 7 $\sim 15 \mathrm{~m}$ - 間隔に坑井を設けて 採掘区画を作るが，運般坑 道，通気，人道㧍よび鉱石集中坑井などは，坑道維持の 上から普通下盤側に設けている。

水平スライス法; 銿押坑道（加背 $2.1 \mathrm{~m} \times 1.8 \mathrm{~m}$ ）開さ く後, $7 \sim 15 \mathrm{~m}$ 間隔に鉱石坑井(加背 $1.5 \mathrm{~m} \times 2.1 \mathrm{~m}$ ) を設 け，銿押坑道天盤より $2 \mathrm{~m}$ の竜頭を残して中段坑道（加 背は普通 $1.5 \mathrm{~m} \times 1.8 \mathrm{~m}$ であるが，銿幅により適宜決定さ れる) を掘進採掘して坑井間の連絡をとる。次に中段坑

$1717\langle 135\rangle$ 
第 5 表 採掘法別工程原単位および直接採掘・採鉱費

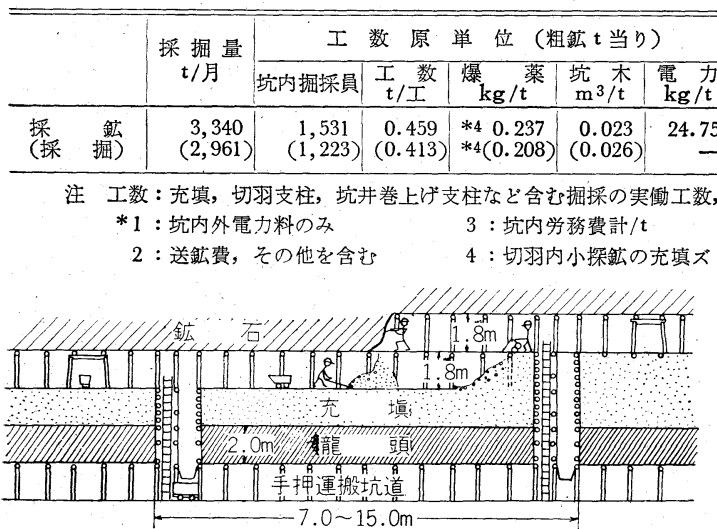

第1図 水平スライス法

道から銿沿いまたはクロスカット（脈幅の広い場合）に 採掘し，連絡坑道を残して同時手バネ充垻する。その後 その連絡坑道の上部を $1.8 \mathrm{~m}$ の高さで 2 段目の採掘に移 る一方, 鉱石坑井の枠を 1 スライスあげて下段の坑道の 充填を行なう。充填ズリは，上下盤への小探鉣ズリを充 当するが, 不足の場合は上部坑道から坑道開さく, 探鉱 ズリをもつて行なう。以後上部坑道までこの水平段欠, 充填を繰返して行なう(第1図)。

サブレベルケービング法; まず下部坑道から 7 15m 間隔に鉱石坑井を設け, 鉱体上端より約 $2 \mathrm{~m}$ の竜頭を残 乙中段坑道を銿沿いに掘進採掘する。次にこれの上 1.8 $\mathrm{m}$ の高さに上り, この坑道の天盤を漸次落して採掘す る。下段の採掘踏前に粗笅, 古材などのいわゆる「マッ ト」を敷きつめ，採掘跡を自然崩落させる。銿幅が特に 広い場合は水平スライス法を併用して一部手バネ充塓す る。1.8m の竜頭を残して順次下段の採掘を同様に行な い，下部坑道まで採掘する(第 2 図)。

これら採掘作業は, 掘採員 2 名のクルー方式を採り, 作業内容が穿孔発破またはピック掘, 下積, 支柱, 充填 作業であるため能率給を加味している。

切羽および中段坑道運搬は， $0.15 \mathrm{t}$ 小型鉱車に人力手 積を普通とするが，ときにはスラッシャを利用する。

切羽支柱は，ほとんど三つ留で枠間約 $1 \mathrm{~m}$ とし，状況 に応じ沿留, 間留を施すこともある。鉱石坑井は打柱張 分け，4つ枠張分けまたは空木積張分けとして人道と区 別している。

\section{3 通気}

総排気坑に $18 \mathrm{PP} 2$ 台の扇風機を設置し, 通洞坑を入気 としている。各切羽, 運搬坑道の主要部には，それぞれ 2 5Hの局扇を設置し，その数 28 台となつている。

\section{4 運 搬}

4 番坑 (通洞坑準) 上部の鉱石は $0.6 \mathrm{t}$ 木鉱車で 4 番 坑鉱石坑井へ落し，下部鉱石は各坑淮鉱石坑井を経て第

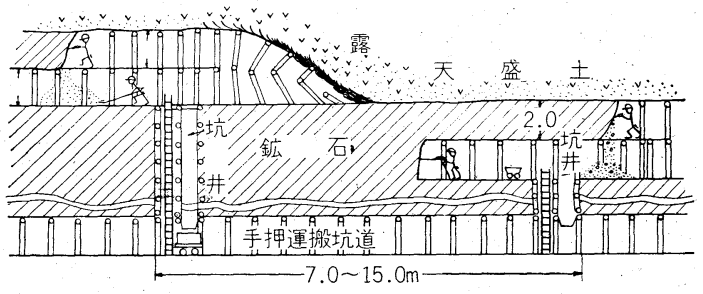

第 2 図 サブレベルケービング法

1 斜坑鈗石集中坑井潗約され，4番坑までスキップ $(1 \mathrm{t})$ で巻上げられる。ここで鉄鉱車 $(0.9 \mathrm{t})$ の13車列

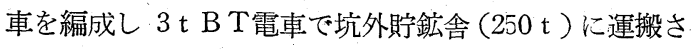
れる。貯鉱舎と選鉱場間はトラック送鉱である。

\section{4. 結}

\section{言}

以上採鈗法の概要を述べたが，鉱石に多量の自然水銀 を含むという特質上，これの完全回収，水銀中毒罹患率 の低下などの重要課題を保安的見地と経費面との両面か ら充分検討し，逐次改善に努める計画である。

第 6 表 過去10年間の年間出鉱量, 平均品位 および能率の推移

\begin{tabular}{|c|c|c|c|c|c|}
\hline & \multirow{2}{*}{$\begin{array}{c}\text { 年間出鉱量 } \\
(\mathrm{t})\end{array}$} & \multirow{2}{*}{$\begin{array}{l}\text { 平均品位 } \\
\mathrm{Hg}(\%)\end{array}$} & \multicolumn{3}{|c|}{1 人 1 月当り出鉱量 $(\mathrm{t})$} \\
\hline & & & 掘採量 & 坑内員 & 坑内外員 \\
\hline $\begin{array}{l}32 \text { 年 } \\
33 \\
34 \\
35 \\
36 \\
37 \\
38 \\
39 \\
40 \\
41 \\
\text { 訫許均 }\end{array}$ & $\begin{array}{r}45,355 \\
41,860 \\
50,922 \\
63,940 \\
63,505 \\
44,294 \\
39,363 \\
50,620 \\
52,479 \\
40,931 \\
493,269 \\
49\end{array}$ & $\begin{array}{l}0.33 \\
0.34 \\
0.29 \\
0.23 \\
0.21 \\
0.23 \\
0.24 \\
0.19 \\
0.17 \\
0.22\end{array}$ & $\begin{array}{l}78.2 \\
85.6 \\
89.7 \\
86.9 \\
86.0 \\
62.3 \\
54.1 \\
52.2 \\
52.2 \\
46.5 \\
6\end{array}$ & $\begin{array}{l}29.2 \\
27.6 \\
33.4 \\
39.8 \\
41.9 \\
33.8 \\
33.6 \\
33.8 \\
32.8 \\
30.1 \\
\end{array}$ & $\begin{array}{l}21.2 \\
21.2 \\
26.9 \\
31.5 \\
32.7 \\
28.8 \\
29.4 \\
28.1 \\
26.9 \\
23.0 \\
\end{array}$ \\
\hline 平 均 & 49,327 & 0.24 & 60.7 & 33.6 & 27.0 \\
\hline
\end{tabular}

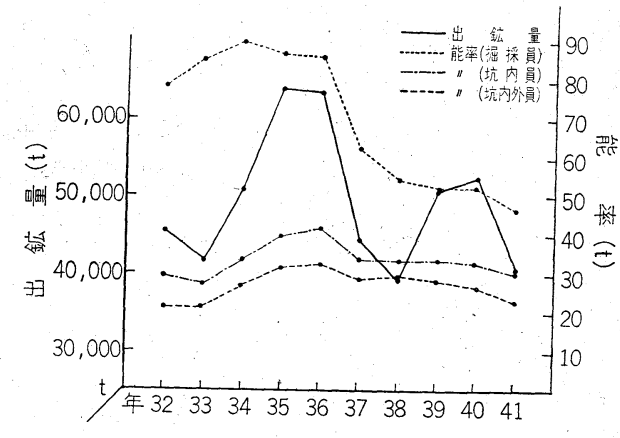

第 3 図 